Piotr Kroczek

Uniwersytet Papieski

Jana Pawła II w Krakowie
Kiedy myślimy Rodzina..., red. M. Duda,

K. Kułek-Sładek, Kraków 2016, s. 263-273

(Praca Socjalna w Teorii i Działaniu, 2).

\title{
Opieka naprzemienna: ocena projektu ustawy (Druk Sejmu VII kadencji nr 3104)
}

\author{
Alternating care: assessment of the bill \\ (Print Sejm seventh term No. 3104)
}

\begin{abstract}
In its ruling on the divorce, the court rules on joint parental authority over a minor child of both spouses. Under the current legal regime, it has become a common practice, that the court delegates the exercise of parental authority to one of the parents, limiting the parental authority of the second parent to specific rights and duties in relation to the child. The proposed amendment to the Act of 25th February 1964 - the Family and Guardianship
\end{abstract}

Code (form 3104) was drafted by the Codification Committee of Family Law that cooperates with the Commissioner for Children's Rights. The new law introduces, co called, an "alternate custody". The solution is to limit the transgression of the child's right to be brought up by both parents. The aim of the paper is to evaluate the bill in question.

Keywords: divorce, alternate custody, welfare of the child, family law

W wyroku orzekającym rozwód sąd, zgodnie z przepisami kodeksu rodzinnego i opiekuńczego ${ }^{1}$, rozstrzyga o władzy rodzicielskiej nad wspólnym małoletnim dzieckiem obojga małżonków. Na ogół - zdaniem Rzecznika

1 Ustawa z dnia 25 lutego 1964 r. - Kodeks rodzinny i opiekuńczy (Dz.U. z 2015 r. poz. 583) [dalej: k.r.o.]. 
Praw Dziecka - sądy powierzają wykonywanie tej władzy jednemu z rodziców, ograniczając władzę rodzicielską drugiego do określonych obowiązków i uprawnień ${ }^{2}$.

Uznając taką praktykę za niesłuszną i wymagającą zmiany, Rzecznik przesłał do Senatu projekt nowelizacji ustawy z dnia 25 lutego 1964 r. - Kodeks rodzinny i opiekuńczy oraz ustawy kodeks postępowania cywilnego. Projekt ten został poprzez uchwałę izby niższej z dnia 9 stycznia 2015 roku wniesiony do Sejmu (druk sejmowy nr $3104^{3}$ ). Należy dodać, że nowelizacja ta została opracowana przez działającą przy Rzeczniku Praw Dziecka Komisję Kodyfikacyjną Prawa Rodzinnego.

Zamierzeniem artykułu jest ocena celów tej ustawy i proponowanych sposobów ich realizacji w zakresie, w jakim dotyczy ona kodeksu rodzinnego i opiekuńczego oraz sytuacji rozwodu rodziców (projekt dotyczy również sytuacji, gdy rodzice nie rozwodzą się, lecz żyją w rozłączeniu - art. 107 k.r.o.).

\section{Ewaluacja celów nowelizacji i ich realizacji}

\subsection{Ochrona praw dziecka}

Nowelizacja kodeksu rodzinnego - zgodnie z uzasadnieniem projektu - ma na celu ograniczenie naruszania prawa dziecka do wychowania przez oboje rodziców. Jest to zdaniem inicjatorów prawo naturalne. W opinii wnioskodawców potrzeba dokonania zmian w prawie wynika z konieczności zwiększenia ochrony wspomnianego prawa dziecka w trakcie konfliktów rodzicielskich, które często istnieją w przypadku rozwodu, poprzez szersze wprowadzenie tzw. opieki naprzemiennej (opieki zrównoważonej), polegającej na pozostawieniu władzy rodzicielskiej obojgu rodzicom w takim samym zakresie ${ }^{4}$.

Należy zgodzić się, że wychowanie dziecka przez obydwoje rodziców jest z punktu widzenia dobra dziecka optymalnym sposobem wykonywania władzy rodzicielskiej. Temu prawu bez wątpienia należy się szeroka ochrona, a moż-

2 Sondażowe badanie aktowe przeprowadzone w 2011 roku przez Instytut Wymiaru Sprawiedliwości wykazało, że w 42,5\% wyroków sądy pozostawiały władzę rodzicielską obojgu rodzicom; E. Holewińska-Łapińska Pozostawienie władzy rodzicielskiej nad wspólnymi małoletnimi dziećmi obojgu rozwiedzionym rodzicom oraz rozstrzygnięcia o kontaktach z dziećmi w wyrokach rozwodowych, Warszawa 2012, s. 4.

3 Dostępny pod adresem: http://www.sejm.gov.pl/sejm7.nsf/druk.xsp?nr=3104 (17.04.2015). Aktualny przebieg procesu legislacyjnego pod adresem: http://www.sejm. gov.pl/sejm7.nsf/PrzebiegProc.xsp?nr=3104 (17.04.2015).

4 Uzasadnienie projektu ustawy (Druk Sejmu VII kadencji nr 3104), s. 2. 
liwości jego pełnej realizacji trzeba mocno promować. Na tym tle należy podnieść kilka uwag wobec wnioskodawców i wykazać pewne niekonsekwencje w ich działaniach.

Po pierwsze, wnioskodawcy starają się zabezpieczyć dobro dziecka głównie w sytuacji rozwodu rodziców. Oznacza to, że chcą oni za pomocą nowych regulacji zmienić niepożądaną z punktu widzenia dziecka sytuację. Jednakże ta właśnie sytuacja jest wynikiem innych regulacji, czyli przepisów dotyczących rozwodu, które wnioskodawcy chcą pozostawić w mocy. W tym miejscu można sformułować dwa wnioski.

1. W osiągnięciu celu, o który chodzi wnioskodawcom, pomogłaby zmiana praktyki orzeczniczej sądów, przykładowo poprzez szersze stosowanie przepisu wyłączającego dopuszczalność rozwodu, gdyby miało na skutek niego ucierpieć dobro wspólnych małoletnich dzieci małżonków (art. $56 \$ 2$ k.r.o.). Należy przypomnieć, że istnieje wymóg właściwego uwzględnienia przez sąd okoliczności dotyczących sytuacji dzieci przy zbieraniu materiału dowodowego oraz że po stronie sądu istnieje obowiązek „uzasadnienia na podstawie szczegółowo ustalonych okoliczności, stanowiska sądu orzekającego rozwód co do tego, czy i jaki wpływ na sytuację wspólnych dzieci małżonków wywrzeć może rozwiąza-

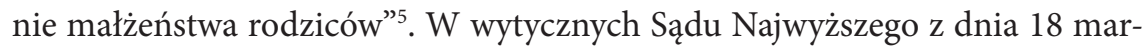
ca 1968 roku dla wymiaru sprawiedliwości i praktyki sądowej w zakresie stosowania przepisów art. 56 oraz art. 58 kodeksu rodzinnego i opiekuńczego, III CZP 70/66 , znajduje się wykładnia powyższego przepisu, która wskazuje sytuacje, w których orzeczenie rozwodu może przynieść uszczerbek dla dobra małoletnich dzieci. Wskazane by było, aby sądy wzorowały się na nich.

2. Dalej idącym wnioskiem jest usunięcie lub zmiana przepisów regulujących ustanie małżeństwa przez rozwód, które powodują niepożądaną sytuację ze względu na wychowanie dziecka. Należałoby się zastanowić, czy nie lepiej byłoby zapobiegać pochopnym rozwodom - które nota bene są sprzeczne z prawem naturalnym - poprzez powrót do stanu prawnego z 1950 roku, kiedy to sądy na podstawie przepisów kodeksu rodzinnego ${ }^{7}$ były obowiązane do analizy przyczyn ustania małżeństwa i tylko w przypadku, gdy przyczyny te były ważne, orzeczenie rozwodu było dopuszczalne (art. $29 \$ 1$ ). Badanie przyczyn rozpadu małżeństwa i ich ocena dokonywana przez sąd, a w konsekwencji odmowa orzeczenia rozwodu przyczyniłaby się do zmniejszenia liczby rozwodów.

5 Wyrok Sądu Najwyższego - Izba Cywilna z dnia 10 maja 2000 r. III CKN 881/00, Legalis nr: 278539; zob. Uchwała Pełnego Składu Izby Cywilnej Sądu Najwyższego z dnia 9 czerwca 1976 r. III CZP 46/75, Legalis nr: 19477.

6 Legalis nr: 13450.

7 Ustawa z dnia 27 czerwca 1950 r. - Kodeks rodzinny (Dz.U. Nr 34, poz. 308 z późn. zm.). 
Po drugie, prawo dziecka do wychowania przez oboje rodziców już jest obecne w polskim systemie prawnym także w sytuacji rozwodu rodziców. Zarówno Konstytucja RP w art. 48 ust. 1, jak i Kodeks rodzinny i opiekuńczy art. $58 \$ 1$ dopuszczają taką możliwość, czyli pozostawienie pełni władzy rodzicielskiej obojgu rozwiedzionym małżonkom. Także art. 18 ust. 1 Konwencji o prawach dziecka ${ }^{8}$ stanowi, że: „Państwa-Strony podejmą wszelkie możliwe starania dla pełnego uznania zasady, że oboje rodzice ponoszą wspólną odpowiedzialność za wychowanie i rozwój dziecka”. Kluczowe prawo dziecka jest więc dobrze zabezpieczone. Kolejne powielenie tej samej normatywnej treści z punktu widzenia techniki legislacyjnej jest zbędne.

Byłoby wskazane, aby wnioskodawcy zastanowili się raczej nad realizacją tego prawa, czyli wypełnieniem zobowiązania Polski wynikającego z ust. 2 przywołanego artykułu Konwencji. Przepis ten zobowiązuje państwo do okazywania odpowiedniej pomocy rodzicom w celu zagwarantowania i popierania praw zawartych w Konwencji w wykonywaniu przez nich obowiązków związanych z wychowywaniem dzieci.

Po trzecie, zdaniem projektodawców ochrona prawa dziecka do wychowania jest „konsekwencją uznania praw dziecka do utrzymywania kontaktów z rodzicami"9. Takie rozumowanie można łatwo sprowadzić ad absurdum stwierdzeniem, że konsekwentnym żądaniem wnioskodawców powinno być wprowadzenie całkowitej niedopuszczalności rozwodu, jeżeli małżonkowie mają wspólne małoletnie dzieci. Przecież najlepszym zabezpieczeniem prawa do kontaktów jest prawo do wychowania, a ono jest zabezpieczone przez niedopuszczalność ustania małżeństwa.

Należy jasno powiedzieć, że odmiennymi instytucjami prawnymi są kontakty oraz wykonywanie władzy nad dzieckiem. Nie wydaje się w tym przypadku, aby była konieczna ochrona jednych uprawnień przez wzmocnienie innych. Prawo dziecka do utrzymywania kontaktów z rodzicami jest jasno wyartykułowane w art. 113 k.r.o. oraz uznane i gwarantowane przez akty prawa międzynarodowego: Konwencję o prawach dziecka z 1989 roku, Konwencję w sprawie kontaktów z dziećmi z 2003 r. ${ }^{10}$ czy Konwencję o jurysdykcji, prawie właściwym, uznawaniu, wykonywaniu i współpracy w zakresie odpowiedzialności rodzicielskiej oraz środków ochrony dzieci z 1996 r. ${ }^{11}$. Tym samym można powiedzieć, że dobro dziecka i prawa rodziców w materii kontaktów zostało wystarczająco zabezpieczone w prawie polskim.

\footnotetext{
Dz. U. z 1991 r. Nr 120, poz. 526.

Uzasadnienie projektu ustawy (Druk Sejmu VII kadencji nr 3104), s. 1.

Dz.U. z 2009 r. Nr 68, poz. 576.

Dz.U. z 2010 r. Nr 172, poz. 1158.
} 
Można dodać, że zasada autonomii rodziny, tak mocno podkreślana przez Europejski Trybunał Praw Człowieka w Strasburgu ${ }^{12}$ oraz przez Kościół ${ }^{13}$, musi mieć także aspekt negatywny. Oznacza to respektowanie prawa rodziców do życia w rozłączeniu oraz autonomię ich decyzji odnośnie do tego, kto będzie wychowywał dziecko w przypadku ustania małżeństwa. Państwo nie może uzurpować sobie prawa do sanacji sytuacji rodzinnej wbrew woli rodziców lub dziecka.

\subsection{Eliminacja niepożądanych zjawisk}

Zdaniem wnioskodawców przyjęcie ocenianego projektu przyczyni się do eliminacji postaw rodziców nieszanujących prawa dziecka do kontaktu z drugim rodzicem oraz dąży do faktycznej separacji dziecka od jednego z rodziców ${ }^{14}$.

Cel, który stawiają sobie autorzy projektu, można uznać za słuszny, jednakże sposób jego osiągnięcia jest utopijny. Niewątpliwie oddzielenie dziecka od jednego z rodziców w sytuacji, gdy kontakty rodzica z dzieckiem nie zagrażają dobru dziecka ani go nie naruszają, odbywa się z uszczerbkiem zarówno dla dziecka, jak i dla rodzica. Jednakże doświadczenie życiowe wskazuje, że brak porozumienia rodziców i ich niechęć do współdziałania w tym zakresie nie mogą być sanowane decyzją sądu. Trudno oczekiwać od rodziców, że podejmą współpracę tylko na podstawie wyroku. Przecież także obecnie, w wyroku orzekającym rozwód, sąd orzeka o kontaktach z dzieckiem (art. $58 \$ 1$ k.r.o.). Jednakże w tej części orzeczenia często nie są respektowane. Samo zagwarantowanie prawne kontaktu dziecka z rodzicem nie oznacza, że do takich kontaktów dochodzić będzie.

Wnioskodawcy podnoszą także, że rozwiązanie przyjęte w art. 58 kodeksu rodzinnego i opiekuńczego powoduje, iż w przypadku braku porozumienia małżonków o sposobie wykonywania władzy rodzicielskiej sąd jest zmuszony do ograniczenia władzy jednemu z nich. W sytuacji konfliktu pozostawienie władzy rodzicielskiej w takim samym zakresie obojgu rodzicom ma zabezpieczyć przed zaostrzeniem się konfliktu i zagwarantować poszanowanie autonomii sędziowskiej, które jest obecnie ograniczone w tym zakresie ${ }^{15}$.

12 Zob. np. ETPC: wyrok w sprawie Olsson przeciw Szwecji (nr 1) z dn. 24 marca 1988 r., 10465/83, Legalis nr: 135629.

13 Sobór Watykański II, Dekret o apostolstwie świeckich Apostolicam actuositatem, [w:] Sobór Watykański II, Konstytucje, dekrety, deklaracje, Poznań 1986, s. 578-627, tu nr 11: „Niech więc sami rodzice i wszyscy wierni współpracują z ludźmi dobrej woli, by w prawodawstwie cywilnym zabezpieczono bezwzględną nietykalność tych praw; rządząc społeczeństwem winno się brać pod uwagę potrzeby rodzinne dotyczące mieszkania, wychowania dzieci, warunków pracy, ubezpieczeń społecznych i podatków; w kierowaniu procesem migracji należy bezwzględnie zabezpieczyć wspólnotę życia rodzinnego”.

14 Uzasadnienie projektu ustawy (Druk Sejmu VII kadencji nr 3104), s. 2.

15 Uzasadnienie projektu ustawy (Druk Sejmu VII kadencji nr 3104), s. 3. 
Odpowiadając na te argumenty trzeba zaznaczyć, że forma naprzemiennego wykonywania władzy rodzicielskiej i sprawowania opieki jest i w obecnym stanie prawnym możliwa, lecz uzależniona w gruncie rzeczy od postawy rodziców i wysokiego prawdopodobieństwa ich współdziałania w wykonywaniu władzy rodzicielskiej. Jak słusznie zauważył Sąd Najwyższy w swoich wytycznych z 1968 roku, pozostawienia pełni władzy rodzicielskiej obojgu rozwiedzionym małżonkom nie można jednak traktować jako reguły. „Wymaga ono bowiem ustalenia, że stosunek wzajemny małżonków oraz inne okoliczności, a przede wszystkim ich dotychczasowy stosunek do dzieci oraz wzajemne kontakty w tym zakresie, zapewniają szanse zgodnego wykonywania przez oboje rodziców władzy rodzicielskiej wspólnie, w sposób odpowiadający dobru dziecka i interesowi społecznemu (art. $95 \$ 3$ )”. Wydaje się, że tylko takie rozwiązanie, oparte właśnie na porozumieniu rodziców, może prognozować udaną współpracę dla dobra dziecka. Wzajemna troska o dziecko, choć wykonywana w rozłączeniu rodziców, jest istotą tej i innych form sprawowania władzy rodzicielskiej.

Doświadczenie życiowe wskazuje, że konflikt pomiędzy rodzicami nie sprzyja wykonywaniu władzy rodzicielskiej nawet w sytuacji, gdy jedno z rodziców ma tę władzę ograniczoną. Tym bardziej nie będzie możliwa współpraca pomiędzy rodzicami mającymi „równą” władzę rodzicielską. Projektodawcy natomiast przewidują, że jeżeli rodzice nie osiągnęli porozumienia, to wówczas „sąd, uwzględniając prawo dziecka do wychowania przez oboje rodziców, rozstrzyga o sposobie wspólnego wykonywania władzy rodzicielskiej i utrzymywania kontaktów z dzieckiem po rozwodzie” (art. $58 \$ 1$ la k.r.o. projekt). Oznacza to, że konflikt rodzicielski nie jest - w świetle projektu - przeszkodą dla równego wykonywania władzy rodzicielskiej, co w gruncie rzeczy jest utopijnym założeniem.

Słusznie uznano, że dobrowolne zobowiązanie się rodziców przed sądem do określonego sposobu sprawowania władzy rodzicielskiej i utrzymywania kontaktów z dzieckiem jest najlepszym gwarantem zabezpieczenia dobra dziecka. Takie zobowiązanie może mieć postać planu wychowawczego. Oczywiście, musi istnieć w ocenie sądu prawdopodobieństwo, że rodzice rzeczywiście będą realizować porozumienie, o którym mowa. Nie można oprzeć się jedynie na deklaracji rodziców. Należy więc postulować, aby wnioskodawcy omawianego projektu nie tyle dążyli do zmiany obwiązujących przepisów, ile szerzej propagowali plan wychowawczy jako formę porozumienia pomiędzy rodzicami. Powinno się to odbywać poprzez udzielanie rozwodzącym się rodzicom pomocy w osiągnięciu porozumienia w tym zakresie. Pomoc ta może przybrać formę podawania wzorów porozumienia wychowawczego, pomocy fachowych pracowników rodzinnych z ośrodków diagnostyczno-konsultacyjnych, me- 
diatorów, terapeutów ${ }^{16}$. Oceniana nowelizacja ustawy de facto chce zastąpić ich wolę porozumienia rodzicielskiego nakazem prawa. Tym samym zmniejszy jego atrakcyjnośćc ${ }^{17}$.

W tym miejscu można podnieść słuszną proponowaną w projekcie zmianę jednego z przepisów kodeksu rodzinnego i opiekuńczego. Zdanie drugie $\mathrm{w}$ art. $58 \$ 1$ ma mieć brzmienie: „Sąd uwzględnia pisemne porozumienie małżonków o sposobie wykonywania władzy rodzicielskiej i utrzymywaniu kontaktów z dzieckiem po rozwodzie, jeżeli jest ono zgodne z dobrem dziecka”. W porównaniu do poprzedniego brzmienia tego przepisu proponuje się doprecyzowanie, że to porozumienie małżonków ma być na piśmie. Pisemność porozumienia, czyli planu wychowawczego przyczyni się do jasnego podziału praw i obowiązków związanych z wykonywaniem władzy rodzicielskiej i kontaktów z dzieckiem. Zmiana ta przyczyni się także do pewności prawnej.

Jednakże, co trzeba zaznaczyć, dotychczasowy stan prawny zezwalał, aby plan wychowawczy był w formie pisemnej. Jednak, jak wskazują badania aktowe, porozumienia, o których mowa, rzadko miały tę formę, a jeżeli nawet tak było, to nie obejmowały one pełnego katalogu zagadnień składających się na treść władzy rodzicielskiej i kontaktów z dziećmi ${ }^{18}$. Należałoby także rozważyć, czy nie powinno się pójść krok dalej i przewidzieć szersze zastosowanie środków kontroli dla wykonywania planów wychowawczych, które są przecież integralną częścią orzeczeń sądowych. Chodzi o skuteczne wpływanie na rodziców w celu wymuszenia respektowania przez nich własnych ustaleń i woli sądu ${ }^{19}$.

Podsumowując ewaluację celów stawianych projektowi, można powiedzieć, że cele te są szlachetne i dobre. Jednakże plan osiągnięcia tych celów jest zły.

Jeżeli Rzecznik Praw Dziecka widzi potrzebę zmian, to powinien wpierw rozważyć, czy korekty nie wymaga wykładnia i aplikacja obowiązujących już przepisów. Sama zmiana stanu prawnego czy jedynie powtarzanie tej samej treści normatywnej w stanowionych przepisach jest raczej przejawem administracyjnego idealizmu niż znajomości zasad rządzących życiem ustawy, czyli jej oddziaływaniem na społeczeństwo. Wprawdzie nie można zwrócić się już do Sądu Najwyższego o wytyczne dla wymiaru sprawiedliwości i praktyki sądowej - ta instytucja prawna jako godząca w zasadę niezawisłości sędziowskiej została znie-

16 Druk Sejmu RP VI kadencji nr 888.

17 Zob. Sąd Najwyższy, Biuro Studiów i Analiz, Opinia o projekcie ustawy o zmianie ustawy Kodeks rodzinny i opiekuńczy (Druk Senatu RP VIII kadencji nr 757), s. 5.

18 Zob. Sąd Najwyższy, Biuro Studiów i Analiz, Opinia z dnia 27 listopada 2014 r. o projekcie ustawy o zmianie ustawy Kodeks rodzinny i opiekuńczy (Druk Senatu RP VIII kadencji nr 757), s. 3-4.

19 Zob. Ministerstwo Sprawiedliwości, Opinia z 26 listopada 2014 r. o projekcie ustawy o zmianie ustawy Kodeks rodzinny i opiekuńczy (Druk Senatu RP VIII kadencji nr 757), s. 2. 
siona w 1989 roku ${ }^{20}$, lecz można poczekać na uchwałę sędziów Sądu Najwyższego w składzie 7 sędziów, która może mieć moc zasady prawnej (art. $61 \S 6$. ustawy o Sądzie Najwyższym² ${ }^{21}$ i przyczynić się do skierowania praktyki sędziowskiej we właściwym kierunku.

\section{Zasada dobra dziecka vs. równość płci}

Patrząc na projekt z pewnej perspektywy można dostrzec, że niejako w jego tle istnieje konfrontacja dwóch wartości chronionych prawem: dobra dziecka i równości płci.

Ta pierwsza wartość stanowi fundamentalną zasadę polskiego prawa rodzinnego ${ }^{22}$. Wymaga ona, aby prawo za najważniejszy cel obierało zawsze dobro dziecka. Zasada ta często jest wprost wyrażana w przepisach, a niekiedy zawarta w nich implicite (zob. art. 72 Konstytucji RP; zob. także: art. $56 \$ 2$, art. 62 i nast., art. 87, art. 92 i nast., art. 133, art. 145 i nast. k.r.o.).

Ta druga z wymienionych wartości jest zawarta w art. 33 Ustawy Zasadniczej i stanowi ogólną zasadę równouprawnienia kobiety i mężczyzny. Ta zasada równości płci ma odzwierciedlenie w wielu szczegółowych uregulowaniach, także prawa rodzinnego. Zasadniczo nic ono nie stanowi o preferencji płci w jakimkolwiek aspekcie. Ogólna zasada brzmi, że kobieta i mężczyzna mają w zakresie praw i obowiązków w małżeństwie równe prawa i obowiązki (art. 23 k.r.o.) ${ }^{23}$.

Te dwie wymienione wartości wydają się w przypadku ocenianego projektu pozostawać w konflikcie. Jednakże należy zwrócić uwagę, że Konstytucja RP $\mathrm{w}$ art. 18 stanowi, iż „macierzyństwo i rodzicielstwo znajdują się pod ochroną i opieką Rzeczypospolitej Polskiej”. Zgodnie z założeniem o racjonalności prawodawcy wymienienie poza rodzicielstwem (czyli ojcostwem i macierzyństwem) dodatkowo macierzyństwa jest celowym działaniem prawodawcy. Takie

20 Ustawa z dnia 20 grudnia 1989 r. o zmianie ustaw - Prawo o ustroju sądów powszechnych, o Sądzie Najwyższym, o Naczelnym Sądzie Administracyjnym, o Trybunale Konstytucyjnym, o ustroju sądów wojskowych i Prawo o notariacie (Dz.U. Nr 73, poz. 436). Zob. szerzej: A. Watoła, Wytyczne wymiaru sprawiedliwości - geneza, podstawowe założenia i ich znaczenie dla sądownictwa powszechnego w pierwszych latach Polski Ludowej, „Z Dziejów Prawa” 11 (2010), t. 3, s. 127-135.

$21 \quad$ Ustawa z dnia 23 listopada 2002 r. o Sądzie Najwyższym (Dz.U. z 2013 r. poz. 499 z późn. zm.).

22 Więcej na temat zasad prawa rodzinnego zob. J. Winiarz, Wprowadzenie, [w:] J. Gajda i inni, Kodeks rodzinny i opiekuńczy. Komentarz, red. K. Pietrzykowski, Warszawa 2010, nb. 39-46.

23 Zob. P. Kroczek, Wychowanie: optyka prawa polskiego i kanonicznego, Kraków 2013, s. $54-58$. 
sformułowanie przepisu ma na celu szczególną ochronę właśnie matki i jej zadań, co oznacza preferencję jednej z płci. Podobnie jest w art. 71 Konstytucji RP w ust. 2: „matka przed i po urodzeniu dziecka ma prawo do szczególnej pomocy od władz publicznych". Zasada egalitaryzmu płci nie jest więc ujmowana przez ustrojodawcę w sposób absolutny.

Przywołać także należy w tym kontekście orzeczenie Sądu Najwyższego z dnia 21 listopada 1952 r., C 1814/52 24. Rozstrzygając kwestię powierzenia władzy rodzicielskiej jednemu z rozwiedzionych rodziców, sąd stwierdził, że powinno się rozważyć, mając na uwadze wiek dziecka, które z rodziców daje większą gwarancję troski o jego fizyczny i duchowy rozwój.

Oznacza to, że egalitaryzm płci jest wartością drugorzędną wobec dobra dziecka. Proponowane w ewaluowanym projekcie zmiany starają się jednak zrównać te zasady. Nota bene, nowelizacje niektórych ustaw, a szczególnie kodeksu pracy ${ }^{25}$, zmierzają w podobnym kierunku co oceniany projekt (por. art. $182^{1}$ i art. $182^{2}$ k.p.). Należy zarówno na poziomie stanowienia prawa, jak i jego realizacji sprzeciwiać się tendencjom absolutyzującym egalitarność płci. Słusznie uznawana równość kobiet i mężczyzn wobec prawa nie może oznaczać niedopuszczalności różnic w unormowaniach wobec nich. Różnice w regulacjach dotyczących kobiet i mężczyzn wynikają z wielu uwarunkowań, np. biologicznych, kulturowych, oraz doświadczeń prawnohistorycznych, a nie z preferowania jednej płci przez ustawodawcę.

\section{Podsumowanie}

Mając powyższe na względzie, należy negatywnie ocenić nowelizację kodeksu rodzinnego i opiekuńczego zgłoszoną przez Rzecznika Praw Dziecka. Jest ona zbędna, a także może okazać się szkodliwa. Sama słuszność celów ocenianego projektu nie wystarczy, aby proponowane zmiany przepisów uznać za pożądane.

Dodatkowo, przedmiotowa nowelizacja została przygotowana z naruszeniem zasad sztuki legislacji, takich jak przykładowo naruszenie zasady stabilności prawa $^{26}$. Błędy w technice legislacyjnej wytykane przez opiniodawców projektu są

\footnotetext{
24 Legalis nr: 683972.

25 Ustawa z dnia 26 czerwca 1974 r. Kodeks pracy (Dz.U. z 2014 r. poz. 1502 $\mathrm{z}$ późn. $\mathrm{zm}$.).

26 Zob. Sąd Najwyższy, Biuro Studiów i Analiz, Opinia z dnia 27 listopada 2014 r. o projekcie ustawy o zmianie ustawy Kodeks rodzinny i opiekuńczy (Druk Senatu RP VIII kadencji nr 757), s. 1 i s. 7.
} 
niekiedy kompromitujące, np. błędy językowe ${ }^{27}$. Projektodawcy nie wzięli w wystarczającym stopniu pod uwagę jednej z podstawowych zasad prawodawstwa, a mianowicie tego, że pożądany efekt w postaci zmiany zachowań użytkowników prawa należy osiągać wpierw na drodze zmiany praktyki stosowania prawa, czyli wykładni przepisów i aplikacji norm, a nie zmiany treści przepisów.

Nota bene, badany projekt jest kolejnym projektem opracowanym przez Komisję Kodyfikacyjną Prawa Rodzinnego przy Rzeczniku Praw Dziecka, który należy ocenić negatywnie ${ }^{28}$. Tym mocniej należy podkreślić, że doniosłość społeczna i prawna każdej niemal zmiany w prawie rodzinnym domaga się większej niż reprezentowana przez Rzecznika Praw Dziecka rozwagi oraz głębszej analizy możliwych skutków proponowanych zmian legislacyjnych.

\section{Bibliografia}

Druk Sejmu RP VI kadencji nr 888; http://orka.sejm.gov.pl/Druki6ka.nsf/0/68047150ED-

DA8EB1C12574B8004D19C7/\$file/888.pdf (17.04.2015).

Druk Sejmu RP VII kadencji nr 3104; http://www.sejm.gov.pl/sejm7.nsf/druk.xsp?nr=3104

(17.04.2015).

Europejski Trybunał Praw Człowieka w Strasburgu, wyrok w sprawie Olsson przeciw Szwecji

(nr 1) z dnia 24 marca 1988 r., 10465/83, Legalis nr 135629.

Gajda J. i inni, Kodeks rodzinny i opiekuńczy. Komentarz, red. K. Pietrzykowski, Warszawa 2010.

Holewińska-Łapińska E., Pozostawienie władzy rodzicielskiej nad wspólnymi małoletnimi dziećmi obojgu rozwiedzionym rodzicom oraz rozstrzygnięcia o kontaktach $z$ dziećmi w wyrokach rozwodowych, Warszawa 2012.

Konwencja o jurysdykcji, prawie właściwym, uznawaniu, wykonywaniu i współpracy w zakresie odpowiedzialności rodzicielskiej oraz środków ochrony dzieci z 1996 r. (Dz. U. z 2010 r. Nr 172, poz. 1158).

Konwencja o prawach dziecka przyjęta przez Zgromadzenie Ogólne Narodów Zjednoczonych dn. 20 listopada 1989 r. (Dz. U. z 1991 r. Nr 120, poz. 526).

Konwencja w sprawie kontaktów z dziećmi z 2003 r., sporządzona w Strasburgu w dniu 15 maja 2003 r. (Dz. U. z 2009 r. Nr 68, poz. 576).

27 Zob. Prokurator Generalny, Opinia z dnia 5 listopada 2014 r. o projekcie ustawy o zmianie ustawy Kodeks rodzinny i opiekuńczy (Druk Senatu RP VIII kadencji nr 757), s. 1.

28 Przykładowo, na dezaprobatę zasługuje projekt ustawy o zmianie Kodeksu rodzinnego i opiekuńczego oraz Kodeksu postępowania cywilnego (Druk Sejmu RP VII kadencji nr 2361), wprowadzający przysposobienie ze wskazaniem. Jego krytyczną ocenę zawiera artykuł: P. Kroczek, Przysposobienie ze wskazaniem: ocena z perspektywy katolickiej i luterańskiej, który ukaże się w „Studia Oecumenica” za 2016 rok. 
Kroczek P., Wychowanie: optyka prawa polskiego i kanonicznego, Kraków 2013.

Ministerstwo Sprawiedliwości, Opinia z 26 listopada 2014 r. o projekcie ustawy o zmianie ustawy Kodeks rodzinny i opiekuńczy (Druk Senatu RP VIII kadencji nr 757), http:// www.sejm.gov.pl/sejm7.nsf/druk.xsp?nr=3104 (3 maja 2015).

Orzeczenie Sądu Najwyższego - Izba Cywilna z dnia 21 listopada 1952 r., C 1814/52, Legalis nr: 683972.

Prokurator Generalny, Opinia z dnia 5 listopada 2014 r. o projekcie ustawy o zmianie ustawy Kodeks rodzinny i opiekuńczy (Druk Senatu RP VIII kadencji nr 757), http://www. sejm.gov.pl/sejm7.nsf/druk.xsp?nr=3104 (17 kwietnia 2015).

Sąd Najwyższy, Biuro Studiów i Analiz, Opinia o projekcie ustawy o zmianie ustawy Kodeks rodzinny i opiekuńczy (Druk Senatu RP VIII kadencji nr 757), http://www.sejm.gov.pl/ sejm7.nsf/druk.xsp?nr=3104 (17 kwietnia 2015).

Sobór Watykański II, Dekret o apostolstwie świeckich Apostolicam actuositatem, [w:] Sobór Watykański II, Konstytucje, dekrety, deklaracje, Poznań 1986, s. 578-627.

Uchwała Pełnego Składu Izby Cywilnej Sądu Najwyższego z dnia 9 czerwca 1976 r. III CZP 46/75, Legalis nr: 19477.

Ustawa z dnia 20 grudnia 1989 r. o zmianie ustaw - Prawo o ustroju sądów powszechnych, o Sądzie Najwyższym, o Naczelnym Sądzie Administracyjnym, o Trybunale Konstytucyjnym, o ustroju sądów wojskowych i Prawo o notariacie (Dz.U. Nr 73, poz. 436).

Ustawa z dnia 23 listopada 2002 r. o Sądzie Najwyższym (tj. Dz.U. z 2013 r. poz. 499 z późn. $\mathrm{zm}$.).

Ustawa z dnia 26 czerwca 1974 r. Kodeks pracy (Dz.U. z 2014 r. poz. 1502 z późn. zm.).

Ustawa z dnia 27 czerwca 1950 r. - Kodeks rodzinny (Dz.U. Nr 34, poz. 308 z późn. zm.).

Ustawa z dnia z dnia 25 lutego 1964 r. - Kodeks rodzinny i opiekuńczy (Dz.U. z 2015 r. poz. 583).

Watoła A., Wytyczne wymiaru sprawiedliwości - geneza, podstawowe założenia i ich znaczenie dla sadownictwa powszechnego w pierwszych latach Polski Ludowej, „Z Dziejów Prawa” 11 (2010) t. 3, s. 127-135.

Wyrok Sądu Najwyższego - Izba Cywilna z dnia 10 maja 2000 r. III CKN 881/00, Legalis nr: 278539.

Wytyczne Sądu Najwyższego z dnia 18 marca 1968 r. dla wymiaru sprawiedliwości i praktyki sądowej w zakresie stosowania przepisów art. 56 oraz art. 58 Kodeksu rodzinnego i opiekuńczego, III CZP 70/66, Legalis nr: 13450. 
A. Uniwersytet Papieski T.5. Jana Pawła II 